Gut, 1974, 15, 165-172

\title{
Liver structure and function in cholelithiasis: Effect of chenodeoxycholic acid ${ }^{1}$
}

\author{
G. D. BELL, H. Y. I. MOK, M. THWE, G. M. MURPHY, K. HENRY, AND \\ R. H. DOWLING ${ }^{2}$ \\ From the Departments of Medicine and Histopathology, Royal Postgraduate Medical School, \\ Hammersmith Hospital, London, and The Institute of Child Health, University of Birmingham
}

SUMMARY Although, in suitable patients, oral chenodeoxycholic acid (CDCA) dissolves gallstones, the results of recent animal studies suggest that it might be hepatotoxic. Liver function was therefore studied in patients with gallstones before and during treatment with CDCA and liver biopsies were carried out both in patients with cholelithiasis given bile acid therapy and in those who had been given no medical treatment. In 25 patients treated with $0.5-1.5 \mathrm{~g} \mathrm{CDCA} /$ day $(7-20 \mathrm{mg} \mathrm{kg}$ body weight ${ }^{-1}$ day $^{-1}$ ) there was no significant change in serum bilirubin, albumin, globulin, transaminase, isocitric dehydrogenase, alkaline phosphatase, and gamma glutamyl transpeptidase levels before and at monthly intervals during six months' treatment. The kinetics of bromsulphthalein (BSP) clearance and its apparent transport maximum were not significantly changed during CDCA therapy. The mean fasting serum bile acid concentrations of $18.0 \pm$ SEM $1.2 \mu$ moles/litre before and $20.0 \pm 3.5 \mu \mathrm{moles} /$ litre during treatment were both significantly greater than control values. Liver histology was not appreciably different in 11 patients treated with CDCA from that in eight patients with untreated cholelithiasis and in three patients who had received CDCA three to four months before biopsy. These results suggest that in doses of 0.5 to $1.5 \mathrm{~g}$ /day CDCA is not hepatotoxic in man.

Oral chenodeoxycholic acid (CDCA) improves cholesterol solubility in bile (Thistle and Schoenfield, 1971) and in suitable patients it dissolves gallstones (Danzinger, Hofmann, Thistle, and Schoenfield, 1972; Bell, Whitney, and Dowling, 1972; Thistle and Hofmann, 1973), but, as with any new drug, the benefits of treatment with CDCA must be weighed against possible complications. One such potential complication is hepatic dysfunction and indeed Small (1971) predicted that this might happen either as a direct effect of CDCA itself on the liver, or indirectly through the formation of lithocholic acid, the bacterial metabolite of CDCA, which is known to be hepatotoxic.

Although the initial reports of CDCA treatment

${ }^{1}$ Presented in part at the Annual Meeting of the Association of Physicians, Glasgow, in April 1973 (Bell et al, Quart.J. Med., 42, 824-825 (Abstr.), 1973.

'Request for reprints to R.H.D., Gastroenterology Unit, Department of Medicine, Guy's Hospital Medical School, London SE1 9RT.

Received for publication 30 January 1974. in man described no significant hepatic dysfunction (Danzinger et al, 1972; Bell et al, 1972) more recent animal studies have again raised the question of hepatotoxicity. In Rhesus monkeys given 40, 80 , or $120 \mathrm{mg} \mathrm{CDCA} \mathrm{kg} \mathrm{body} \mathrm{weight}{ }^{-1}$ day $^{-1}$ by mouth for six months, there were raised levels of serum alkaline phosphatase and oxaloacetic transaminase while liver histology showed bile duct hyperplasia and mononuclear infiltration of the portal tracts (Lee, 1973, personal communication).

It is not yet known whether these changes in liver structure and function are confined to the Rhesus monkey and therefore a study of the effects of CDCA on the liver in man is of fundamental importance if further patients with cholesterol gallstones are to be treated with this bile acid. This paper presents our own results for liver structure in patients with gallstones during treatment with CDCA and in those who had been given no medical therapy, and liver function in patients with gallstones before and during treatment with chenodeoxycholic acid for periods up to 15 months. 


\section{The Patients}

Twenty-eight patients with radiologically proven gallstones (six men and 22 women) were treated with CDCA for periods ranging from six weeks to 15 months. Their mean age was $50 \cdot 2$ years (range $24-$ 75). The criteria for selecting these patients for treatment have already been described (Bell et al, 1972).

DOSE OF CDCA

In 25 patients the dose of CDCA ranged from 0.5 to $1.5 \mathrm{~g}$ per day (equivalent to approximately 7-20 $\mathrm{mg} / \mathrm{kg}$ body weight) while three patients received only $0.25 \mathrm{~g}$ per day $(3.5 \mathrm{mg} / \mathrm{kg}$ body weight).

\section{Methods}

\section{STUDIES OF LIVER STRUCTURE AND} FUNCTION

Liver function was studied by measuring the levels of circulating liver enzymes and serum bile acids, by following the kinetics of BSP clearance from the plasma after an intravenous bolus injection of BSP $(5 \mathrm{mg} / \mathrm{kg})$, and by measuring the apparent transport maximum (Tm) of BSP (Wheeler, Meltzer, and Bradley, 1960). Liver structure was studied by light microscopic examination of percutaneous Menghini needle and intraoperative wedge and needle biopsies of the liver.

Serum bilirubin, albumin, and globulin levels These were measured by standard laboratory methods before and at monthly intervals during treatment.

\section{Circulating liver enzymes}

The levels of two hepatocellular enzymes, serum glutamic oxaloacetic transaminase (SGOT) and isocitrate dehydrogenase (ICD), and two 'biliary tract' enzymes, alkaline phosphatase and gamma glutamyl transpeptidase (GGT), were also measured before, and in most cases at monthly intervals during, bile acid treatment using standard laboratory methods.

\section{Bromsulphthalein studies}

The kinetics of BSP clearance were measured in eight patients with gallstones receiving CDCA and in five patients with gallstones who had not been treated. Following a bolus injection of BSP into one antecubital vein $(5 \mathrm{mg} / \mathrm{kg}$ body weight), blood samples were taken from the opposite arm at five, 10, $15,20,30,35,40,45,50$, and 60 minutes. The fall in plasma concentration of BSP was then plotted against time.
The apparent transport maximum (Tm) and storage capacity (S) of BSP (Wheeler et al, 1960) were measured in six patients during CDCA treatment and in four patients with gallstones who had received no treatment. In one patient, the apparent BSP Tm and $S$ were measured before and again after three months' treatment with $1.0 \mathrm{~g}$ CDCA per day.

\section{Serum bile acids}

The total fasting serum bile acid concentrations were measured at least $12 \mathrm{hr}$ after the last dose of CDCA by spectrofluorimetry combined with the hydroxy steroid dehydrogenase enzyme assay (Murphy, Billing, and Baron, 1970). Six estimations were made in five untreated patients with gallstones and in 12 patients receiving $0.25-1.0 \mathrm{~g} / \mathrm{CDCA}$ per day. The results in both groups were then compared with the findings in a control group of 24 subjects (12 male and 12 female) previously studied by one of us (G.M.M.).

\section{LIVER STRUCTURE}

Before the recent results, showing that CDCA was toxic to the liver of Rhesus monkeys (Lee, 1973), we had not felt justified in performing liver biopsies on relatively asymptomatic patients with gallstones who had normal conventional liver function tests. However, after it became known that structural changes might occur in the liver of primates, liver biopsies were performed in a series of patients with gallstones. Clinical details of the patients studied together with the results of their liver histology are given in table $\mathbf{I}$.

Eight patients with gallstones who had not been treated with CDCA had liver biopsies (three percutaneous needle biopsies and five operative needle biopsies obtained during elective cholecystectomy) and 11 patients who had been treated with 0.25-1 g CDCA/day for periods ranging from six weeks to 15 months (eight had Menghini needle biopsies, two had wedge biopsies, and one an intraoperative needle biopsy). In addition, liver biopsies were obtained in three patients, three to four months after CDCA treatment had been withdrawn (two percutaneous and one operative needle biopsy) one of whom had also been biopsied during therapy. Informed consent was obtained in all cases.

\section{Results}

SERUM BILIRUBIN, ALBUMIN, AND

GLOBULIN LEVELS

These levels were essentially normal throughout the 


\begin{tabular}{|c|c|c|c|c|c|c|c|c|c|c|c|}
\hline \multirow[t]{3}{*}{ Group } & \multirow[t]{3}{*}{ Patient } & \multirow[t]{3}{*}{ Sex } & \multirow[t]{3}{*}{ Age } & \multicolumn{2}{|c|}{ CDCA Treatment } & \multirow[t]{3}{*}{ Biopsy ${ }^{1}$} & \multicolumn{5}{|c|}{ Positive Histological Features } \\
\hline & & & & \multirow{2}{*}{$\begin{array}{l}\text { Duration } \\
\text { (months) }\end{array}$} & \multirow{2}{*}{$\begin{array}{l}\text { Average } \\
\text { Dose } \\
\text { (g/day) }\end{array}$} & & \multicolumn{3}{|c|}{ Parenchyma } & \multicolumn{2}{|l|}{ Portal Tracts } \\
\hline & & & & & & & $\begin{array}{l}\text { Fatty } \\
\text { Change }\end{array}$ & $\begin{array}{l}\text { Lipo- } \\
\text { fuscin }\end{array}$ & Other Features & $\begin{array}{l}\text { Bile Duct } \\
\text { Proliferation }\end{array}$ & $\begin{array}{l}\text { Round Cell } \\
\text { Infiltrate }\end{array}$ \\
\hline \multirow[t]{3}{*}{$\begin{array}{l}\text { I } \\
\text { (patients with } \\
\text { gallstones not } \\
\text { treated with CDCA.) }\end{array}$} & $\begin{array}{l}1 \\
2 \\
3 \\
4\end{array}$ & $\begin{array}{l}\mathbf{F} \\
\mathbf{M} \\
\mathbf{F} \\
\mathbf{F}\end{array}$ & $\begin{array}{l}60 \\
59 \\
47 \\
48\end{array}$ & $\begin{array}{l}- \\
-\end{array}$ & $\begin{array}{l}- \\
-\end{array}$ & $\begin{array}{l}\mathbf{O N}_{\mathbf{N}} \\
\mathbf{O N}_{\mathbf{N}} \\
\mathbf{O}_{\mathbf{N}} \\
\mathbf{O} \mathbf{N}\end{array}$ & $\begin{array}{l}0 \\
++ \\
0 \\
0\end{array}$ & $\begin{array}{l}0 \\
\pm \\
\pm \\
++\end{array}$ & $\begin{array}{l}0 \\
0 \\
0 \\
\begin{array}{l}\text { Occasional poly- } \\
\text { morphs in } \\
\text { sinusoids }\end{array}\end{array}$ & $\begin{array}{l}\mathbf{0} \\
\mathbf{0} \\
\mathbf{0} \\
\mathbf{0}\end{array}$ & $\begin{array}{l}0 \\
+ \\
0 \\
0\end{array}$ \\
\hline & $\begin{array}{l}5 \\
6\end{array}$ & $\begin{array}{l}\mathbf{F} \\
\mathbf{F}\end{array}$ & $\begin{array}{l}50 \\
73\end{array}$ & - & - & $\begin{array}{r}\mathbf{O} N \\
\mathbf{P C}\end{array}$ & $\begin{array}{l}\mathbf{0} \\
\mathbf{0}\end{array}$ & $\begin{array}{l}+ \\
\pm\end{array}$ & $\begin{array}{l}0 \\
\text { Occasional poly- } \\
\text { morphs in } \\
\text { sinusoids }\end{array}$ & $\begin{array}{ll}0 & \\
& \text { Oedema }\end{array}$ & + \\
\hline & $\begin{array}{l}7 \\
8\end{array}$ & $\begin{array}{l}\mathbf{F} \\
\mathbf{F}\end{array}$ & $\begin{array}{l}47 \\
25\end{array}$ & $\overline{-}$ & - & $\begin{array}{l}\text { PC N } \\
\text { PC N }\end{array}$ & $\begin{array}{l}\mathbf{0} \\
\mathbf{0}\end{array}$ & $\begin{array}{l}+ \\
\pm\end{array}$ & $\begin{array}{l}\mathbf{0} \\
\mathbf{0}\end{array}$ & $\begin{array}{l}\mathbf{0} \\
\mathbf{0}\end{array}$ & $0^{+}$ \\
\hline \multirow[t]{6}{*}{$\begin{array}{l}\text { II } \\
\text { (patients with } \\
\text { gallstones biopsied } \\
\text { during treatment } \\
\text { with CDCA) }\end{array}$} & $\begin{array}{r}9 \\
10\end{array}$ & $\begin{array}{l}\mathbf{F} \\
\mathbf{F}\end{array}$ & $\begin{array}{l}70 \\
70\end{array}$ & $\begin{array}{l}15 \\
14\end{array}$ & $\begin{array}{l}1 \cdot 0 \\
1.0\end{array}$ & $\begin{array}{l}\text { PC N } \\
\text { PC N }\end{array}$ & $\mathbf{0}^{++}$ & $\stackrel{ \pm}{0}$ & $\begin{array}{l}\mathbf{0} \\
\text { Occasional poly- } \\
\text { morphs in } \\
\text { sinusoids }\end{array}$ & $\begin{array}{l}0 \\
0\end{array}$ & $\begin{array}{l}\mathbf{0} \\
\mathbf{0}\end{array}$ \\
\hline & $\begin{array}{l}11^{2} \\
12 \\
13 \\
14\end{array}$ & $\begin{array}{l}\mathbf{F} \\
\mathbf{F} \\
\mathbf{M} \\
\mathbf{F}\end{array}$ & $\begin{array}{l}44 \\
56 \\
65 \\
56\end{array}$ & $\begin{array}{l}12 \\
10 \\
12 \\
12\end{array}$ & $\begin{array}{l}1 \cdot 0 \\
0.25 \\
1.0 \\
0.75\end{array}$ & $\begin{array}{l}P C N \\
P C N \\
P C N \\
P C N\end{array}$ & $\begin{array}{l}0 \\
0 \\
0 \\
0\end{array}$ & $\begin{array}{l}+ \\
+ \\
\pm \\
+\end{array}$ & $\begin{array}{l}0 \\
0 \\
0 \\
\text { Occasional poly- } \\
\text { morphs in } \\
\text { sinusoids }\end{array}$ & $\begin{array}{l}+ \\
0 \\
0 \\
0\end{array}$ & $\begin{array}{l}0 \\
+ \\
+ \\
+\end{array}$ \\
\hline & $\begin{array}{l}15 \\
16\end{array}$ & $\begin{array}{l}\mathbf{F} \\
\mathbf{M}\end{array}$ & $\begin{array}{l}62 \\
56\end{array}$ & $\begin{array}{r}11 \\
6\end{array}$ & $\begin{array}{l}0.25 \\
0.75\end{array}$ & $\begin{array}{l}P C N \\
P C N\end{array}$ & $\stackrel{+}{0}$ & $\begin{array}{l} \pm \\
+\end{array}$ & $\begin{array}{l}0 \\
0 \\
\end{array}$ & Pus cells in bi & ile duct lumina \\
\hline & 17 & $\mathbf{F}$ & 33 & 1.5 & 0.75 & sw & 0 & \pm & $\begin{array}{l}\text { Polymorphs, } \\
\text { especially round } \\
\text { central vein }\end{array}$ & $\mathbf{0}$ & + \\
\hline & 18 & $\mathbf{F}$ & 24 & 2 & 0.75 & sw & 0 & + & $\begin{array}{l}\text { Polymorphs }++ \\
\text { Hepatic cell } \\
\text { necrosis }\end{array}$ & \pm & + \\
\hline & 19 & $\mathbf{F}$ & 66 & 2 & 0.25 & $\mathbf{P C} \mathbf{N}$ & $\mathbf{0}$ & \pm & 0 & 0 & $\mathbf{0}$ \\
\hline \multirow{3}{*}{$\begin{array}{l}\text { III } \\
\text { (patients with } \\
\text { gallstones previously } \\
\text { treated with CDCA) }\end{array}$} & $11^{8}$ & $\mathbf{F}$ & 44 & $\begin{array}{l}12 / 12 \text { till } \\
3 / 12 \text { before } \\
\text { biopsy }\end{array}$ & $e^{1 \cdot 0}$ & PC N & $\mathbf{0}$ & + & $\mathbf{0}$ & + & $\mathbf{0}$ \\
\hline & 20 & $\mathbf{F}$ & 52 & $\begin{array}{l}14 / 12 \text { till } \\
4 / 12 \text { before } \\
\text { biopsy }\end{array}$ & $e^{1 \cdot 0}$ & $\mathbf{O} \mathbf{N}$ & + & ++ & 0 & $\mathbf{0}$ & + \\
\hline & 21 & $\mathbf{F}$ & 33 & $\begin{array}{l}3 / 12 \text { till } \\
3 / 12 \text { before } \\
\text { biopsy }\end{array}$ & $e^{1 \cdot 0}$ & $\mathbf{P C} \mathbf{N}$ & 0 & \pm & 0 & 0 & 0 \\
\hline
\end{tabular}

Table I Liver histology in patients with gallstones before and after treatment with CDCA

'Biopsy $\mathbf{P C N}=$ percutaneous $M e n g h i n i$ needle, $\mathrm{ON}=$ operative needle, $\mathrm{SW}=$ surgical wedge

'Histological features, $0=$ absent or normal, $t=$ trace or very slight, $+=$ minimal, $++=$ moderate, $+++=$ moderate to marked

'Patient no. 11 biopsied both during treatment and after chenodeoxycholic acid had been withdrawn

\begin{tabular}{|c|c|c|c|c|c|}
\hline \multirow[t]{3}{*}{ Serum Enzyme } & \multirow[t]{3}{*}{ Normal Range } & \multicolumn{4}{|c|}{ Mean Serum Level $\pm S E M$} \\
\hline & & \multirow{2}{*}{$\begin{array}{l}\text { Before Treatment } \\
(N=\text { no. of } \\
\text { patients })\end{array}$} & \multicolumn{3}{|c|}{ After Treatment with Chenodeoxycholic Acid } \\
\hline & & & $1 / 12$ & $3 / 12$ & $6 / 12$ \\
\hline $\begin{array}{l}\text { Alkaline phosphatase } \\
\text { (KAU) }\end{array}$ & $3-13$ & $\underset{(27)}{6 \cdot 3} \pm 0 \cdot 4$ & $\frac{6 \cdot 2^{1}}{(27)} \pm 0 \cdot 3$ & $\frac{6 \cdot 5^{1}}{(22)} \pm 0.4$ & $\underset{(21)}{6.2^{1}} \pm 0.4$ \\
\hline $\begin{array}{l}\text { GGT } \\
\text { (IU) }\end{array}$ & $2-25$ & $\begin{array}{l}16 \cdot 3 \\
(12)\end{array}$ & $\begin{array}{l}19 \cdot 2^{1} \pm 3 \cdot 8 \\
(12)\end{array}$ & $\begin{array}{l}16 \cdot 7^{1} \pm 3 \cdot 5 \\
(11)\end{array}$ & $\begin{array}{l}19 \cdot 0^{1} \pm 5 \cdot 7 \\
(10)\end{array}$ \\
\hline $\begin{array}{l}\text { SGOT } \\
\text { (IU) }\end{array}$ & $2-20$ & $\begin{array}{l}10 \cdot 3 \\
(23)\end{array}$ & $\frac{12 \cdot 2^{1}}{(23)} \pm 1 \cdot 0$ & $\begin{array}{l}11 \cdot 1^{1} \pm 0.8 \\
(21)\end{array}$ & $\begin{array}{l}10 \cdot 1^{1} \\
(20)\end{array}$ \\
\hline $\begin{array}{l}\text { ICD } \\
\text { (IU) }\end{array}$ & $3-8$ & $\begin{array}{l}9 \cdot 2 \\
(21)\end{array}$ & $\begin{array}{l}10 \cdot 0^{1} \pm 1 \cdot 0 \\
(21)\end{array}$ & $\begin{array}{l}9 \cdot 3^{1} \\
(22)\end{array}$ & $\underset{(19)}{8 \cdot 2^{1}} \pm 0 \cdot 7$ \\
\hline
\end{tabular}

Table II Serum alkaline phosphatase, gamma glutamyl transpeptidase, SGOT, and ICD before and after treatment with chenodeoxycholic acid in a dose of 0.5 to $1.5 \mathrm{~g}$ per day in patients with gallstones

${ }^{1}$ Not significant 
period of treatment. There was no change in any of the mean values before and after CDCA.

\section{CIRCULATING LIVER ENZYMES}

Representative results of the four serum liver enzymes studied are shown by the findings before and during therapy with $0 \cdot 5-1.5 \mathrm{~g}$ CDCA/day at one, three, and six months (table II). There was no significant change in the mean levels of any of the four enzymes studied.

\section{Alkaline phosphatase}

The range of readings before treatment was 4-10 KA units and 3-11 units while on treatment. There were no values outside our normal laboratory range (3-13 KAU).

\section{Gamma glutamyl transpeptidase (GGT)}

The range before therapy was 6-30 IU and during treatment 4-65 IU (N 2-25 IU). Four patients showed fluctuating levels of GGT, greater than the normal range, on at least one occasion. Of these four patients, one took night sedation with barbiturates while a second admitted to a moderately heavy alcoholic intake.

Serum glutamic oxaloacetic transaminase (SGOT) (N2-20IU)

The range before treatment was 7-16 IU and during treatment 5-22 IU. Four patients showed transient elevations of SGOT to levels just above the normal laboratory range but all returned to normal spontaneously without reduction in the dose of bile acid.

\section{Isocitrate dehydrogenase (ICD) (N 3-8 IU)}

The mean level in 21 patients with gallstones before starting treatment of $\mathbf{9 \cdot 2} \pm \mathbf{0 . 8}$ (range 3-16) was above the upper limit of normal-nine of the 21 patients having mildly elevated ICD levels before starting CDCA (fig 1). Although occasional patients showed increased ICD values during treatment, there was no consistent trend to raised levels (range after treatment 2-20).

\section{BROMSULPHTHALEIN STUDIES}

Clearance of a single bolus injection ( $5 \mathrm{mg} / \mathrm{kg}$ )

There was no difference in the mean plasma disappearance curves over the first 25 minutes (fig 2). However, during the next 35 minutes, the eight patients with cholelithiasis treated with CDCA cleared the dye more rapidly than the controls, although the difference between the two groups at 45 , 50, and 60 minutes did not reach statistical significance.

\section{Apparent transport maximum (Tm)}

The mean BSP Tm in the six treated patients of
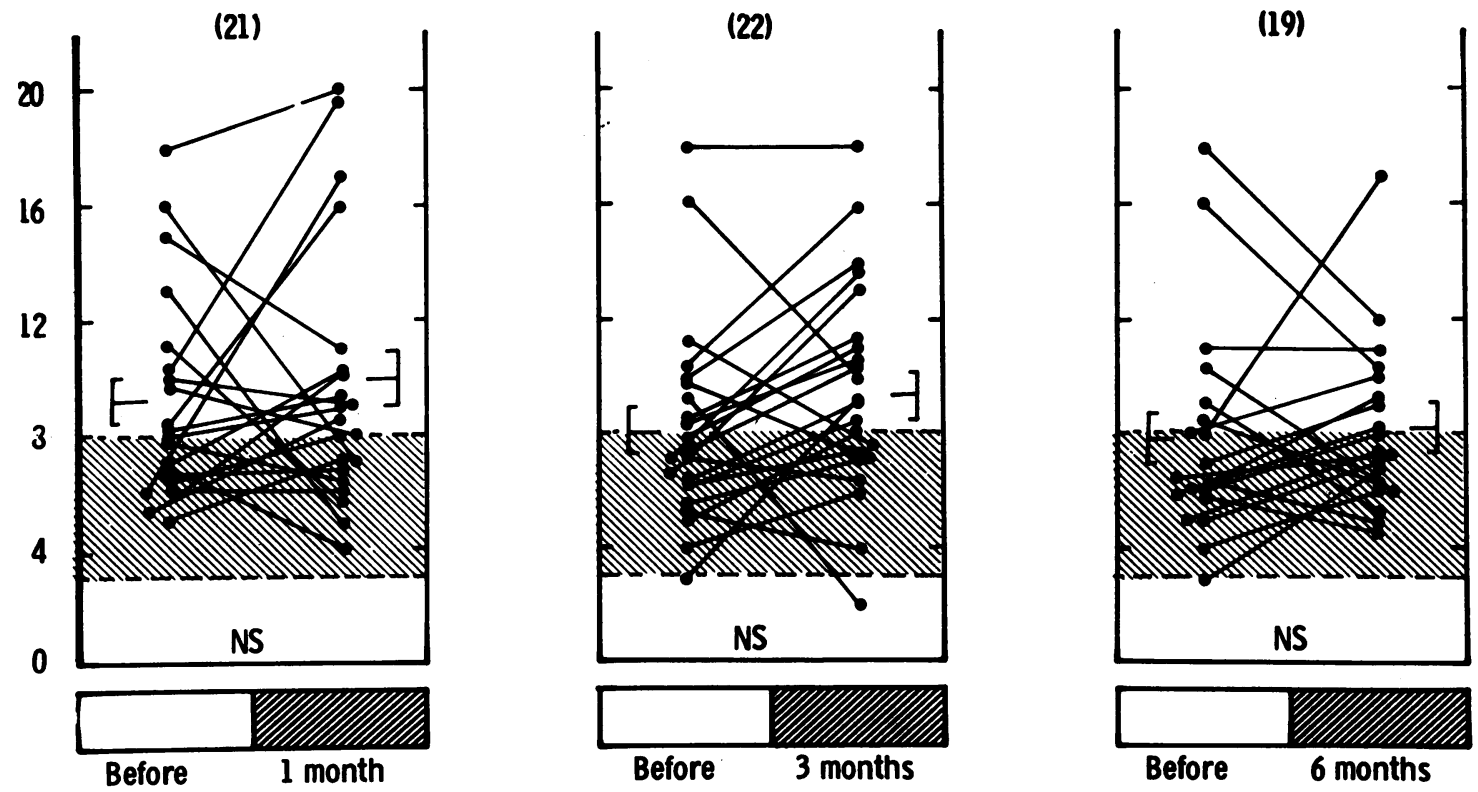

Fig 1 Serum isocitric dehydrogenase levels before and after one, three, and six months' treatment with 0.75 to $1.0 \mathrm{~g}$ chenodeoxycholic acid/day. The normal laboratory range is shown as the crosshatched zones between broken lines. The E-shaped symbols indicate mean values \pm SEMs. 


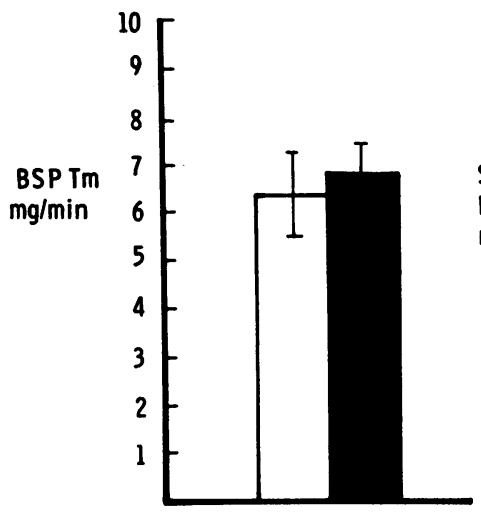

Apparent Tm
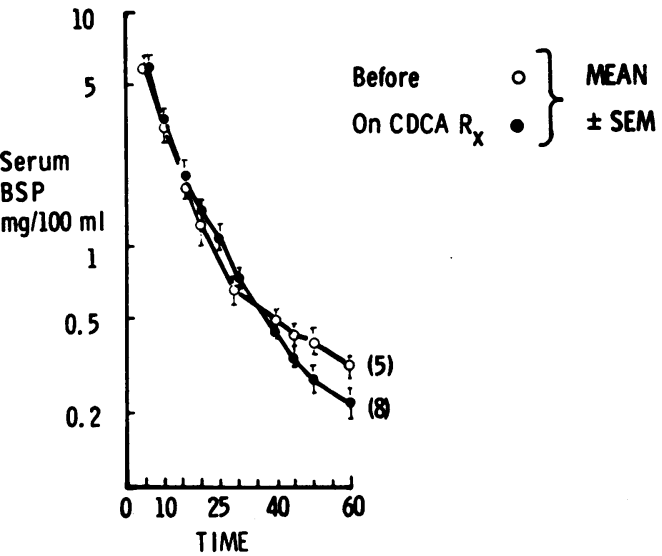

Clearance following bolus

injection $(5 \mathrm{mg} / \mathrm{Kg})$

Fig 2 The apparent BSP transport maximum excretory capacity (Wheeler et al, 1960) measured in patients with gallstones who had received no treatment (open histogram) or $1 \mathrm{~g} C D C A /$ day for three months (closed histogram; mean values \pm SEMs). The semilogarithmic plot shows the clearance of a single bolus injection of BSP (5 mg/kg body weight) in patients given CDCA (closed circles) and in patients who had received no bile acids (open circles).

$6 \cdot 86 \mathrm{mg} / \mathrm{min}$ (range $4 \cdot 0-8 \cdot 1$ ) was essentially the same as in the four untreated patients with gallstones (mean 6.38; range $4.6-7.7 \mathrm{mg} / \mathrm{min}$ ). In one patient, studied before and after treatment, the Tm was again unchanged, being $7 \cdot 1 \mathrm{mg} / \mathrm{min}$ before and $7 \cdot 3$ $\mathrm{mg} / \mathrm{min}$ three months after $0.75 \mathrm{~g} \mathrm{CDCA} /$ day. The rapid late phase of clearance of the single bolus injection of BSP in patients treated with CDCA was therefore not associated with an increased maximum excretory capacity (Tm).

\section{FASTING SERUM BILE ACIDS}

The results of total serum bile acid levels are shown in figure 3. Based on six estimations in five patients with gallstones who had not been treated, the mean value of $18.0 \pm 1.2$ (range 14.0-23.5) $\mu$ moles/litre was not significantly different from the mean value of 20.0 ( \pm 3.5 ; range $3 \cdot 2-56.0 \mu$ moles/litre) in 12 patients treated with 0.25-1.0 g CDCA/day. However, the results in both groups of patients were significantly greater than those in the control population. These modest rises in fasting serum bile acid concentrations were never associated with pruritus.

LIVER STRUCTURE

The positive histological features on liver histology are summarized in table $I$. Of the 11 patients treated with CDCA who had liver biopsies (table I, group II) only two showed significant changes on histology. In one, there was mild proliferation of bile ducts and in another there was moderate to

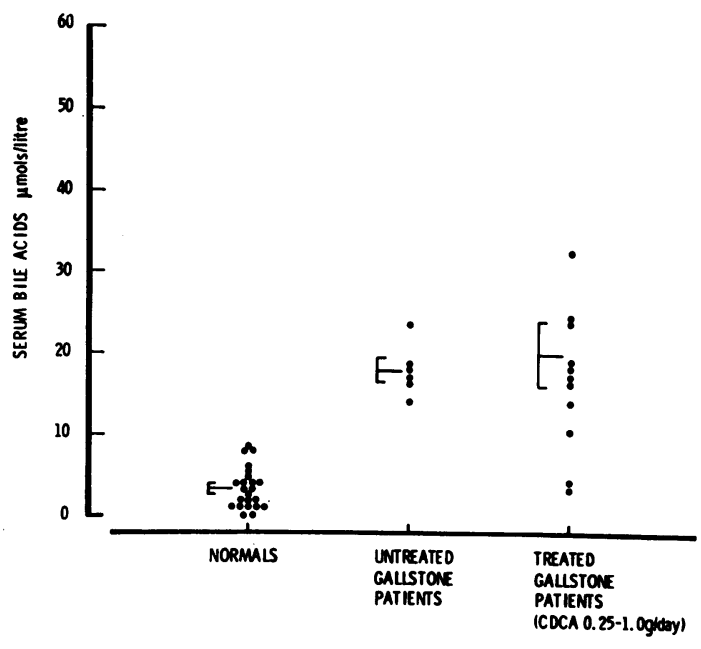

Fig 3 Fasting serum bile acid concentrations ( $\mu$ moles/ litre) in control subjects, in untreated patients with gallstones, and in patients given 0.25-1.0 g CDCA/day. The ' $E$ ' symbols show mean values \pm SEMs.

marked fatty change in the absence of diabetes, obesity and a history of alcohol intake. In other patients in this group there was a minimal increase in mononuclear cells in the portal tracts but this was not thought to be significant. In the control group, all of whom had cholelithiasis (table I, group I), four of the eight patients showed this latter nonspecific change and one further patient showed moderate fatty change. In the three patients in 
whom treatment with CDCA had been stopped for three to four months before biopsy (group III), one showed mild to moderate fatty change and another mild ductular proliferation.

Wedge biopsies were obtained from two of the treated patients at the time of operation and in both there was appreciable infiltration with polymorph neutrophils associated in one case with necrosis of isolated single hepatocytes. This feature was not noted in needle biopsies. Furthermore, occasional polymorphs were seen within sinusoids in about half of all the patients biopsied, irrespective of whether the biopsy was obtained during surgery or percutaneously.

The lipofuscin content within hepatocytes was very variable, but there was no apparent difference between the three groups. There was no relationship between these minor histological changes and the results of liver function tests.

\section{Discussion}

In spite of the reports that CDCA may adversely affect the liver of adult (Lee, 1973) and foetal Rhesus monkeys (Heywood, Palmer, Foll, and Lee, 1973), the present results suggest that in doses of up to $1.5 \mathrm{~g}$ /day, CDCA is not significantly hepatotoxic in man.

There is little previous information about the effects of bile acid feeding on liver structure and function in man. Danzinger et al (1972) initially found that during treatment with up to $4.5 \mathrm{~g} \mathrm{CDCA} /$ day there was no change in liver function. However, in a subsequent, more detailed report from the same unit (Thistle and Hofmann, 1973) nine out of 31 patients showed transient slight rises in SGOT levels which returned spontaneously to normal with continued bile acid treatment. These raised transaminase levels contrast with the normal SGOT values found in the present series, which may be due to the lower doses of CDCA used in our studies.

We found no change in total serum bilirubin levels during treatment, and, although Thistle and Hofmann (1973) did find a significant increase in unconjugated bilirubin, the increase was slight and occurred within the normal range. In an earlier report we described raised ICD levels after three months' treatment with CDCA (Bell et al, 1972) but this was not confirmed in the present study with a larger number of patients. However, in almost half of the patients described here the serum ICD levels were slightly greater than normal before treatment, suggesting that gallstones themselves may cause mild hepatocellular dysfunction. Indeed, in a recent study from Japan, Iwamura, Shimura, Koike,
Yanagisawa, Mokino, Kimura, and Sadatsuki (1973) found 'hepatitic' changes in serum enzymes from 43 out of $\mathbf{4 6}$ patients with cholecystolithiasis.

The increased serum bile acid levels seen in our patients before treatment would also suggest mild hepatic dysfunction since serum bile acids are raised in many types of liver disease (Carey, 1958; Neale, Lewis, Weaver, and Panveliwalla, 1971; Murphy, Ross, and Billing, 1972; Back, 1973) and may even be the most sensitive index of liver disease (Kaplowitz, Kok, and Javitt, 1972; Trash, Gallo, Barnes, and Morris, 1973). Raised serum bile acids in untreated patients with gallstones have not been described previously.

The significance of the occasionally raised gamma glutamyl transpeptidase levels during treatment is uncertain. This enzyme is a sensitive marker of biliary tract disease but it may also be raised in hepatocellular dysfunction (Whitfield, Pounder, Neale, and Moss, 1972) or following microsomal induction with barbiturates (Whitfield, Moss, Neale, Orme, and Breckenridge, 1973). It is possible, therefore, that the raised GGT levels in one of the four patients was due to barbiturates while in a second patient the fluctuating GGT levels may have been related to alcohol intake.

The results of the BSP studies again suggest that oral CDCA is not hepatotoxic in man. We had previously noted that in patients treated with CDCA, the 45-min BSP retention values were, if anything, lower than normal (Bell et al, 1972) and the more rapid late phase of BSP clearance noted here supports this observation. This may be due to the fact that, in experimental animals at least, bile acids have been shown to increase the capacity of the liver to excrete BSP (O'Maille, Richards, and Short, 1966; Barnhart, Ritt, Ware, and Combes, 1973; Erlinger and Dumont, 1973; Forker and Gibson, 1973).

The raised serum bile acids seen during treatment have also been reported by others (James, Cullen, and Bouchier, 1973; Schwarz and Paumgartner, 1973). Although this could indicate hepatic dysfunction, increased serum bile acid concentrations have also been described in the blind loop syndrome and following ileal resection where there are excess quantities of free bile acids in the intestine (Lewis, Panveliwalla, Tabaqchali, and Wootton, 1969). Treatment with the free form of CDCA may therefore raise serum bile acids by a similar mechanism. We are currently studying this by measuring the clearance of isotopic bile acids from the serum.

The minor histological changes seen on liver biopsy are difficult to interpret but the frequency of positive features was the same whether or not the patients had been treated with CDCA. This suggests 
that the cholelithiasis itself rather than the bile acid treatment was responsible for the changes seen on liver histology. Indeed, in a recent study more than half of 616 patients with gallstones showed some degree of liver damage on biopsy (Reichmann, Wohlgemuth, and Schwokowski, 1973) while Hadziyannis, Feizi, Scheuer, and Sherlock (1969) found oedema and inflammation of portal tracts on liver histology in three out of six patients with untreated cholelithiasis. Polymorphonuclear leucocyte infiltrates and hepatic cell necrosis were seen on wedge biopsies in two patients who had been treated with CDCA. However, Keller and Smetana (1950) have suggested that these changes may be artefacts in wedge biopsies due to traction on the liver and proximity of an inflamed gallbladder.

The results of liver biopsies in the present paper are similar to Thistle and Hofmann's findings (1973). Of their 11 patients biopsied, liver histology was normal in eight, showed fatty change in one, minimal periportal infiltration in another, and a moderate degree of periportal fibrosis in a third. Since our original report on liver structure and function during CDCA therapy, another preliminary communication has described similar minimal liver biopsy changes in 10 patients treated with CDCA (James et al, 1973a; James, Scheuer, and Bouchier, 1973b).

In contrast to the sparse information about the effects of bile acid feeding on the liver in man, there have been many studies of hepatic structure and function after giving bile acids to experimental animals. For example, bile duct hyperplasia and frank hepatic cirrhosis have been found in rabbits given either CDCA or its bacterial metabolite, lithocholic acid (Holsti, 1960, 1962) and similar changes have been seen in rats after lithocholate (Carey, Hoffbauer, Zaki, and Nwokolo, 1965; Carey, Wilson, Zaki, and Hanson, 1966; Palmer, 1969), in hamsters and mice following CDCA (Bergman and van der Linden, 1973), in guinea pigs fed lithocholate (Palmer, 1969), and in monkeys given CDCA (Hunt, 1965; Lee, 1973; Heywood et al, 1973; Webster, Lancaster, Wease, Hofmann, and Baggenstoss, 1973). Only one of our patients showed bile duct hyperplasia, the most consistent abnormality seen in experimental animals given either lithocholate or chenodeoxycholate.

In studies of bile lipid secretion in the Rhesus monkey (Bell, Nundy, and Dowling, 1973) we also found that oral CDCA increased, rather than decreased, the saturation of bile with cholesterol and this paradoxical response may be yet another manifestation of hepatic dysfunction after CDCA in this species. The abnormal results in animals, therefore, are quite different to the normal findings in patients treated with CDCA. The adverse effects of bile acid feeding in experimental animals may represent species sensitivity and one cannot extrapolate dose responses per $\mathrm{kg}$ body weight from one species to the next but the changes in hepatic structure and function in subhuman species emphasize the need for vigilance if further patients with gallstones are to be treated with CDCA.

Whatever the effect of bile acid feeding in animals, the results of clinical studies in patients with gallstones must ultimately determine whether or not CDCA is toxic to the liver and much further work is needed before its safety is established. At present, the doses of CDCA used to dissolve gallstones in man have been chosen empirically and have varied from centre to centre. Basic questions about the bioavailability of CDCA, the efficiency of absorption of different doses, their capacity to change cholesterol solubility in bile and to dissolve gallstones, and whether constant or loading plus maintenance doses are more effective, have yet to be answered. The present limited data suggest that in doses up to $1.5 \mathrm{~g} /$ day CDCA is not hepatotoxic in man. It is hoped that more detailed long-term studies will confirm this because CDCA does seem to be an effective treatment for dissolving gallstones in suitable patients.

We wish to thank the patients for their helpful cooperation, the Chemical Pathology Department and Dr D. Moss for the results of serum liver enzymes, Professor K. Weinbren of the Department of Histopathology for his advice on liver histology, and our surgical colleagues who performed the intraoperative liver biopsies. We are grateful to Messrs Weddel Pharmaceuticals (GDB and HYIM), the World Health Organization (MT), and the Medical Research Council (RHD) for financial support. Mrs Hazel Creed kindly typed the script.

\section{References}

Back, P. (1973). Identification and quantitative determination of urinary bile acids excreted in cholestasis. Clin. chim. Acta, 44, 199-207.

Barnhart, J., Ritt, D., Ware, A., and Combes, B. (1973). A comparison of the effects of taurocholate and theophylline on BSP excretion in dogs. In The Liver. Quantitative Aspects of Structure and Function, edited by G. Paumgartner and R. Preisig, pp. 315325. Karger, Basle.

Bell, G. D., Whitney, B., and Dowling, R. H. (1972). Gallstone dissolution in man using chenodeoxycholic acid. Lancet, 2, 1213-1216.

Bell, G. D., Nundy, S., and Dowling, R. H. (1973). Effects of bile acid feeding on bile lipid composition in the rhesus monkey. (Abstr.) Europ. J. clin. Invest., 3, 211.

Bergman, F., and van der Linden, W. (1973). Liver morphology and gallstone formation in hamsters and mice treated with chenodeoxycholic acid. Acta path microbiol scand. A, 81, 213-221.

Carey, J. B., Jr. (1958). The serum trihydroxy-dihydroxy bile acid 
ratio in liver and biliary tract disease. J. clin. Invest., 37, 1494 1503.

Carey, J. B., Jr., Hoff bauer, F. W.,Zaki, F. G., and Nwokolo, C. (1965). Choledocholithiasis and hepatic ductular proliferation induced in rats by lithocholic acid (a bile acid occurring naturally in man). (Abstr.) Gastroenterology, 48, 809-810.

Carey, J. B., Jr., Wilson, I. D., Zaki, F. G., and Hanson, R. F. (1966). The metabolism of bile acids with special reference to liver injury. Medicine (Baltimore), 45, 461-470.

Danzinger, R. G., Hofmann, A. F., Schoenfield, L. J., and Thistle, J. L. (1972). Dissolution of cholesterol gallstones by chenodeoxycholic acid. New Engl. J. Med., 286, 1-8.

Erlinger, S., and Dumont, M. (1973). Influence of canalicular bile flow on sulfobromophthalein transport maximum in bile in the dog. In The Liver. Quantitative Aspects of Structure and Function, edited by G. Paumgartner and R. Preisig, pp. 306314. Karger, Basle.

Forker, E. L., and Gibson, G. (1973). Interaction between sulfobromophthalein (BSP) and taurocholate. The kinetics of transport from liver cells to bile in rats. In The Liver. Quantitative Aspects of Structure and Function, edited by G. Paumgartner and R. Preisig, pp. 326-336. Karger, Basle.

Hadziyannis, S., Feizi, T., Scheuer, P. J., and Sherlock, S. (1969). Immunoglobulin-containing cells in the liver. Clin. exp. Immunol., 5, 499-514.

Heywood, R., Palmer, A. K., Foll, C. V., and Lee, M. R. (1973). Pathological changes in fetal Rhesus monkey induced by oral chenodeoxycholic acid. (Letter.) Lancet, 2, 1021.

Holsti, P. (1960). Cirrhosis of the liver induced in rabbits by gastric instillation of 3-monohydroxycholanic acid. Nature (Lond.), 186, 250.

Holsti, P. (1962). Bile acids as a cause of liver injury: cirrhogenic effect of chenodesoxycholic acid in rabbits. Acta path. microbiol. scand., 54, 479.

Hunt, R. D. (1965). Proliferation of bile ductules (the ductular cell reaction) induced by lithocholic acid. (Abstr.) Fed. Proc., 24, 431.

Iwamura, K., Shimura, S., Koike, H., Yanagisawa, F., Mokino, K. Kimura, K., and Sadatsuki, T. (1972). Clinical and pathological findings of the liver in patients with cholelithiasis. (Abstr.) Gastroent. jap., 7, 184-185.

James, O., Cullen, J., and Bouchier, I. A. D. (1973a). A study of the effectiveness, toxicity and bile salt kinetics of chenodeoxycholic acid in the treatment of human gallstones. (Abstr.) Gut, 14, 827.

James, O. F. W., Scheuer, P. J., and Bouchier, I. A. D. (1973b). The effect of chenodeoxycholic acid on liver function and histology in man. (Abstr.) Digestion, 8, 432.

Kaplowitz, N., Kok, E., and Javitt, N. B. (1973). Postprandial serum bile acid for the detection of hepatobiliary disease. J. Amer. med. Ass., 225, 292-293.

Keller, T. C., and Smetana, H. F. (1950). Artefacts in liver biopsies. Amer. J. clin. Path., 20, 738-741.
Lee, M. R. (1973). Personal communication.

Lewis, B., Panveliwalla, D., Tabaqchali, S., and Wootton, I. D. P. (1969). Serum-bile-acids in the stagnant-loop syndrome. Lancet, 1, 219-220.

Murphy, G. M., Billing, B. H., Baron, D. N. (1970). A fluorimetric and enzymatic method for estimation of serum total bile acids. J. clin. Path., 23, 594-598.

Murphy, G. M., Ross, A., and Billing, B. H. (1972). Serum bile acids in primary biliary cirrhosis. Gut, 13, 201-206.

Neale, G., Lewis, B., Weaver, V., and Panveliwalla, D. (1971). Serum bile acids in liver disease. Gut, 12, 145-152.

O'Maille, E. R. L., Richards, T. G., and Short, A. H. (1966). Factors determining the maximal rate of organic anion secretion by the liver and further evidence on the hepatic site of action of the hormone secretin. J. Physiol. (Lond.), 186, 424-438.

Palmer, R. H. (1969). Toxic effects of lithocholic acid and related $5 \beta$, -H steroids. In Bile Salt Metabolism, edited by L. Schiff J. B. Carey, and J. M. Dietschy, pp. 184-204. Thomas, Springfield, Illinois.

Reichmann, J., Wohlgemuth, B., and Schwokowski, Ch. F. (1973). Leberschäden beim Gallensteinleiden. Z. ges. inn. Med., 28, 327-330.

Schwarz, H. P., and Paumgartner, G. (1973). Elevation of serum bile acids following therapeutic doses of chenodeoxycholic acid in man. (Abstr.) Digestion, 8, 431-432.

Small, D. M. (1971). Prestone gallstone disease-is therapy safe? New Engl. J. Med., 284, 214-216.

Thistle, J. L. and Hofmann, A. F. (1973). Efficacy and specificity of chenodeoxycholic acid therapy for dissolving gallstones. New Engl. J. Med., 289, 655-659.

Thistle, J. L., and Schoenfield, L. J. (1971). Induced alterations in composition of bile of persons having cholelithiasis. Gastroenterology, 61, 488-496.

Trash, D. B., Gallo, G. A., Barnes, S., and Morris. J. S. (1973). The diagnostic value of postprandial bile salt estimations in patients with liver disease. (Abstr.) Gut, 14, 819.

Webster, K. H., Lancaster, M. C., Wease, D. F., Hofmann, A. F., and Baggenstoss, A. H. (1973). The effect of primary bile acid feeding on cholesterol metabolism and hepatic function and morphology in the Rhesus monkey. (Abstr.) Gastroenterology, 65,576 .

Wheeler, H. O., Meltzer, J. I., and Bradley, S. E. (1960). Biliary transport and hepatic storage of sulfobromophthalein sodium in unanesthetised dog, in normal man, and in patients with hepatic disease. J. clin. Invest., 39, 1131-1144.

Whitfield, J. B., Moss, D. W., Neale, G., Orme, M., and Breckenridge, A. (1973). Changes in plasma $\gamma$-glutamyl transpeptidase activity associated with alterations in drug metabolism in man. Brit. med. J., 1, 316-318.

Whitfield, J. B., Pounder, R., Neale, G., and Moss, D. W. (1972). Serum gamma glutamyl transpeptidase activity in liver disease. Gut, 13, 702-708. 